\section{Efficient In Vitro Plant Regeneration from Internode Explants of Ibervillea sonorae: An Antidiabetic Medicinal Plant}

\author{
Ilse-Yazmín Arciniega-Carreón, Carmen Oliver-Salvador ${ }^{1}$ \\ and María-Guadalupe Ramírez-Sotelo \\ Laboratorio de Biotecnología Molecular, Unidad Profesional Interdisciplinaria \\ de Biotecnología del Instituto Politécnico Nacional (UPIBI-IPN), Av. \\ Acueducto s/n C.P. 07340, Colonia La Laguna Ticomán, Ciudad de México, \\ México
}

\section{Carlos Edmundo Salas}

Departamento de Bioquímica, Instituto de Ciências Biológicas, Universidade Federal de Minas Gerais, Belo Horizonte, 31270-901, $M G$, Brasil

Additional index words. micropropagation, cucurbitaceae, callus culture, internode explant, hypoglycemic

\begin{abstract}
Ibervillea sonorae is a medicinal plant mainly used to treat diabetes, ulcers, and other metabolic disorders. A regeneration protocol using internode segments containing axillary buds grown on Gamborg medium (B5) supplemented with $0.5 \mathrm{mg} \cdot \mathrm{L}^{-1}$ $\alpha$-naphthalene-acetic acid (NAA), $0.5 \mathrm{mg} \cdot \mathrm{L}^{-1} \mathrm{~N} 6-$-benzyladenine (BA), and $1.0 \mathrm{mg} \cdot \mathrm{L}^{-1}$ indole-3-acetic acid (IAA) successfully regenerated shoots in $I$. sonorae explants. The induction of organogenic calli attained $100 \%$ efficiency. The highest percent shoot production was $87.5 \%$ with a mean of 9.17 shoots per explant on day 15 , and the maximum length of $5.8 \mathrm{~cm}$ was observed on day 21 . Regenerated shoots induced roots in $B 5$ medium supplemented with $0.5-3.0 \mathrm{mg} \cdot \mathrm{L}^{-1}$ indole-3-butyric acid (IBA). The maximum rooting frequency observed in the medium containing $2.0 \mathrm{mg} \cdot \mathrm{L}^{-1}$ IBA was $83.3 \%$ which promoted long, thick roots on day 21 . The plantlets with emerging roots grown at the culture facility attained $50 \%$ survival after acclimatization for $30 \mathrm{~d}$. The account describes a simple and efficient protocol for in vitro plant regeneration, and this micropropagation procedure offers an alternative for preservation of this medicinal plant.
\end{abstract}

From ancient times, florae are source of compounds for the treatment of diseases. It is estimated that around $75 \%$ of the world's population currently depends on plants as source of traditional medicine (Arias et al., 2009; Rao and Ravishankar, 2002). Medicinal plants contain therapeutic molecules, whose active principles also serve as precursors for drug synthesis (Loraine and Mendoza-Espinoza, 2010).

Ibervillea sonorae (S. Watson) Greene is a medicinal wild perennial plant usually known as "wereke" or "guareque," traditionally used to treat diabetes, ulcers, and

Received for publication 20 Mar. 2017. Accepted for publication 1 June 2017.

The authors would like to acknowledge the financial support by Instituto Politécnico Nacional, México SIP 20140775, SIP 20141244, 20151038. C. Oliver-Salvador is the recipient of a fellowship from Comisión de Operación y Fomento de Actividades Académicas-IPN. I. Y. Arciniega-Carreón is the recipient of a scholarship from Consejo Nacional de Ciencia y Tecnología, México.

${ }^{1}$ Corresponding author. E-mail: moliver@ipn.mx. metabolic disorders (Johnson et al., 1996; Xolalpa, 2002). It belongs to the Cucurbitaceae family, and it is native to arid areas from northern Mexico (Lira and Caballero, 2002; Xolalpa and Aguilar, 2006). It produces secondary metabolites such as alkaloids, tannins, saponins (Alarcon-Aguilar et al., 2005), flavonoids, phenols, (Zapata-Bustos et al., 2014) and cucurbitacins (Achenbach et al., 1993; Jardón-Delgado et al., 2014). Pharmacological studies show that plant root extracts display hypoglycemic and antiinflammatory (Alarcon-Aguilar et al., 2005; Jardón-Delgado et al., 2014; Rivera-Ramírez et al., 2011; Zapata-Bustos et al., 2014), antioxidant (Estrada-Zuñiga et al., 2012), antimicrobial (Robles-Zepeda et al., 2011), and antifungal activities (Ruiz-Bustos et al., 2009). A recent study conducted on human preadipocyte cells showed that aqueous root extracts from I. sonorae stimulate glucose uptake by a PI3K independent pathway (Zapata-Bustos et al., 2014). This evidence supports the antidiabetic properties attributed to $I$. sonorae roots in traditional medicine. The widespread demand of $I$. sonorae roots for therapeutic purposes threatens their survival; therefore, an action is required to protect this species (Gómez-Aiza, 2011).

Cell and tissue culturing are valid alternatives for in vitro production of secondary metabolites with biological activity because they are independent of seasonal factors. A standardized protocol for in vitro micropropagation represents a suitable option for the conservation of endangered species or propagation of variants with a desired phenotype (Elias et al., 2015). Many of these protocols have been developed for regeneration of cucurbitaceous species, like cucumber (Cucumis sativus) (Kim et al., 2010; Kumar et al., 2003a), winter squash (Cucurbita maxima Duch.) (Lee et al., 2003), ash gourd (Benincasa hispida) (Thomas and Sreejesh, 2004), summer squash (Cucurbita pepo L.) (Kathiravan et al., 2006), spiny gourd (Momordica dioica Roxb.) (Devendra et al., 2009), athalaikai and kakrol (Momordica tuberosa) (Aileni et al., 2009), melon gubat (Melothria maderaspatana Linn.) (Baskaran et al., 2009), fig-leaf gourd (Cucurbita ficifolia Bouche) (Kim et al., 2010), balsam apple (Momordica balsamina) (Thakur et al., 2011), telakuch (Coccinea cordifolia) (Roy et al., 2012), ridge gourd (Luffa acutangula L. Roxb.) (Zohura et al., 2013), and bitter melon (Momordica charantia L.) (Sammaiah et al., 2014). Moreover, micropropagation in vitro has been reported using shoot and nodal explants of cucurbitaceous Cucumis sativus, Trichosanthes dioica (Ahmad and Anis, 2005; Kumar et al., 2003b). Despite this profuse account on Cucurbitaceae, no records are available for regeneration of I. sonorae except for one report on calli induction using leaf explants (Estrada-Zuñiga et al., 2012). Therefore, the aim of this work is to establish a protocol for in vitro regeneration of $I$. sonorae to serve as a plant repository, and to define the growth conditions for subsequent establishment of cell-suspension cultures aiming the production of secondary metabolites as well.

\section{Materials and Methods}

Plant material. I. sonorae (S. Watson) Greene plants $(\approx 750 \mathrm{~g})$ were obtained at the local Sonora market, Mexico City, Mexico. The plant internode containing axillary buds (NXB) was selected as the source of explants.

Explant decontamination was done according to the procedure modified by EstradaZuñiga et al. (2012). The explants were washed with $1 \%(\mathrm{v} / \mathrm{v})$ Extran detergent solution (Merck) for $10 \mathrm{~min}$ and rinsed with distilled water, followed by immersion in $70 \%(\mathrm{v} / \mathrm{v})$ ethanol for $30 \mathrm{~s}$, then transferred to a $1.2 \%(\mathrm{v} / \mathrm{v})$ sodium hypochlorite solution diluted from a $5 \%$ commercial stock $\left(\right.$ Cloralex $\left.^{\circledR}\right)$ for $10 \mathrm{~min}$ and finally rinsed four times with sterile-distilled water. The explants were excised into $0.4-0.8 \mathrm{~cm}$ length fragments that were separately cultured in flasks containing Murashige and Skoog (MS) (Murashige and Skoog, 1962) or Gamborg medium (B5) (Gamborg et al., 1968)supplemented 
with various concentrations and combinations of plant growth regulators (BA, IAA, and NAA).

Organogenic callus induction and adventitious shoot regeneration. The explants were grown on basal media comprising MS (4.3 g. $\mathrm{L}^{-1}$ or B5 $\left.3.1 \mathrm{~g} \cdot \mathrm{L}^{-1}\right)$ supplemented with $25 \mathrm{~g} \cdot \mathrm{L}^{-1}$ sucrose, $150 \mathrm{mg} \cdot \mathrm{L}^{-1}$ ascorbic acid, $6 \mathrm{~g} \cdot \mathrm{L}^{-1}$ agar-agar, and growth regulators. The cultures were then incubated in a growth chamber maintained at $25 \pm 2{ }^{\circ} \mathrm{C}$ under $16 \mathrm{~h}$ photoperiod $\left(50 \mu \mathrm{mol} \cdot \mathrm{m}^{-2} \cdot \mathrm{s}^{-1}\right.$, daylight fluorescent tubes). To determine the best concentrations of growth regulators for shoot induction, we applied a two level full factorial design $\left(2^{k}=2^{3}\right)$ using the growth regulators BA, IAA, and NAA as the three factors (Gardiner and Gettinby, 1998). In this study, the most efficient auxin/cytokinin ratio in MR medium for the production of organogenic callus and regenerated shoots derived from NXB explant was investigated. Besides, the frequency of shoot induction and the number of regenerated shoots per explant were recorded after $15 \mathrm{~d}$ of culture.

Conditions for root induction. To establish the culturing conditions for root induction, proliferating shoots $(4-6 \mathrm{~cm}$ length and $21-\mathrm{d}-$ old) with one or two leaves were excised and transferred to B5 medium supplemented with IBA. Different IBA concentrations were assayed to determine the optimal condition for root induction. These conditions were chosen by factorial design [one factor multilevel, equation: $Y=3.62+20.8 A$, where $Y$ is the response (root induction), and $A$ is the IBA factor] (Gardiner and Gettinby, 1998). The culturing conditions were similar to those described in section "Organogenic callus induction and adventitious shoot regeneration." The number of emerging roots and the root length of explants bearing shoots were recorded by day 21. Shoots containing roots were removed from the culture and after rinsing with a $1 \%(\mathrm{v} / \mathrm{v})$ aqueous nystatin were separately placed inside plastic pots containing a commercial potting soil mix $\mathrm{pH} 6.0$ (Hydro-Environment) containing 20\% perlite, $20 \%$ vermiculite, $20 \%$ humus, and $40 \%$ peatmoss. The pots were covered with transparent polythene bags and irrigated with sterilized tap water. The plantlets were incubated in an ambient with $33 \%$ humidity under conditions similar to those described in the section "Organogenic callus induction and adventitious shoot regeneration."

Statistical analysis. Statistical analysis of the effect of each growth regulator on the frequency of regenerated shoots and rooting efficacy were determined with Statistical Analysis System (SAS) and online University Edition and Minitab (Statistical Software Version 16), respectively. Each experiment was repeated three times. Data were analyzed using analysis of variance, and the significance of differences between means was determined via Tukey's test at 5\% significance level.

\section{Results}

Callus Induction and shoot regeneration. Experiments were initially designed to compare
B5 and MS media efficacies to induce calli from root explants supplemented with IAA, NAA, and BA. The B5 medium was 3.8fold more efficient than the MS medium to induce calli under similar conditions. In addition, calli grown on B5 increased their mass 4.5-fold, whereas MS-grown calli exhibited a 2 -fold mass increase after $15 \mathrm{~d}$ in culture (data not shown).

Following optimization of calli induction from root explants, a screening for the best conditions to optimize shoot induction was implemented using NXB explants. In these experiments, B5 or MS medium required supplementation with growth regulators (IAA, NAA, and BA) to stimulate shoot formation. The absence of any of them obliterated this effect (Table 1). Overall, B5 medium was more efficacious than MS as shoot inducer in I. sonorae NXB explants. At low concentration $\left(0.5 \mathrm{mg} \cdot \mathrm{L}^{-1}\right)$ of each growth regulator, only $\mathrm{B} 5$ medium induced shoots $(23.3 \pm 7.5 \%)$. The highest shoot induction $(96.7 \pm 4.7 \%)$ was observed in B5 when concentration of IAA was $1 \mathrm{mg} \cdot \mathrm{L}^{-1}$, whereas the concentration of BA and NAA were kept constant at $0.5 \mathrm{mg} \cdot \mathrm{L}^{-1}$. Besides, the same treatment enhanced shooting in MS medium to a lower degree $(30.0 \%)$. The optimal shooting effect in MS medium $(40 \pm 8.1 \%)$ occurred when increasing BA to $1 \mathrm{mg} \cdot \mathrm{L}^{-1}$ while keeping IAA and NAA at 1.0 and $0.5 \mathrm{mg} \cdot \mathrm{L}^{-1}$, respectively. Interestingly, at $0.5 \mathrm{mg} \cdot \mathrm{L}^{-1} \mathrm{IAA}$ and $1.0 \mathrm{mg} \cdot \mathrm{L}^{-1} \mathrm{NAA}$ no shoot induction in $\mathrm{B} 5$ or MS medium was evident, regardless the concentration of BA (Table 1).

Therefore, we adopted the optimized conditions as shown on Table 1 (BA $0.5 \mathrm{mg} \cdot \mathrm{L}^{-1}$, IAA $1.0 \mathrm{mg} \cdot \mathrm{L}^{-1}$, and NAA $0.5 \mathrm{mg} \cdot \mathrm{L}^{-1}$ ) and named the MR medium in subsequent experiments to induce organogenic calli and regenerate shoot in NXB explants. The dynamic of these events is summarized in Fig. 1A-D. Figure 1A shows green organogenic calli on day 5 of culture and white organogenic calli from day 7 of culture (Fig. 1B). On day 15 , they are shown regenerating shots from green calli (Fig. 1C) and white calli (Fig. 1D).

Furthermore, under this condition, organogenic calli sprouted on day 5 at the ends of internodes in contact with the medium. White friable calli were 2.7 times more abundant than green calli and their masses increased $\approx 4$-fold by day 15 (Table 2 ) regardless the color of calli (green calli, Fig. 1A; white calli, Fig. 1B). After one week, it was observed that regenerated shoots emerged more frequently $(3.5 \mathrm{x})$ in friable white calli than in green calli (Table 3).

On emerging white-calli, the first shoots appeared between 5-8 d (Fig. 1B). After culturing for $15 \mathrm{~d}$, internodes with axillary buds emerged, and the frequency of shoot induction was $87.5 \pm 14.4 \%$ (Fig. 1D; Table 3$)$. On the other hand, green calli showed lower frequency of induced shoots $(25 \pm 4.0 \%)$ and their shoots emerged around day 13 (Fig. 1C; Table 3). At the end of the elongation period $(15-20 \mathrm{~d})$, the regenerated shoots attained 4-6 cm length.

Figure 1E displays the elongating shoots. Using the optimized MR medium, the addition of fresh growing medium to stimulate elongation of regenerated shoots was not necessary. After $20 \mathrm{~d}$ in MR culture, $70.8 \pm$ $19.1 \%$ of the regenerated shoots grew up, averaging $9.17 \pm 2.9$ shoots per explant, exhibiting normal appearance and no signs of hyperhydricity (Fig. 1F). These shoots were selected for further rooting experiments.

Root induction. Cultures of organogenic white calli from NXB explants, displaying the largest number of regenerated shoots (10 \pm 1.9 shoots per explant) and averaging $4.44 \pm 0.3 \mathrm{~cm}$ (data not shown) were used to evaluate the rooting ability. In the absence of IBA, shoots survived up to $10 \mathrm{~d}$ after transplantation without emergence of roots. Successful rooting was observed in regenerated shoots grown in B5 medium supplemented with IBA (Table 4). Between 0.5 and 1.0 $\mathrm{mg} \cdot \mathrm{L}^{-1}$ IBA, rooting attained $6.6 \%$ to $20 \%$, respectively. Most shoots failed to generate

Table 1. Effect of medium and concentration of growth regulators on shoot induction in I. sonorae NXB explants.

\begin{tabular}{|c|c|c|c|c|}
\hline $\mathrm{BA}\left(\mathrm{mg} \cdot \mathrm{L}^{-1}\right)$ & IAA $\left(\mathrm{mg} \cdot \mathrm{L}^{-1}\right)$ & NAA $\left(\mathrm{mg} \cdot \mathrm{L}^{-1}\right)$ & Percent shoot induction B5 & Percent shoot induction MS \\
\hline$\overline{-}$ & - & - & $0 \mathrm{a}$ & $0 \mathrm{a}$ \\
\hline 0.5 & - & - & $0 \mathrm{a}$ & $0 \mathrm{a}$ \\
\hline 1 & - & - & $0 \mathrm{a}$ & $0 \mathrm{a}$ \\
\hline - & 0.5 & - & $0 \mathrm{a}$ & $0 \mathrm{a}$ \\
\hline - & 1 & - & $0 \mathrm{a}$ & $0 \mathrm{a}$ \\
\hline - & - & 0.5 & $0 \mathrm{a}$ & $0 \mathrm{a}$ \\
\hline - & - & 1 & $0 \mathrm{a}$ & $0 \mathrm{a}$ \\
\hline 0.5 & 0.5 & 0.5 & $23.30 \pm 7.45 b$ & $0 \mathrm{a}$ \\
\hline 1 & 0.5 & 0.5 & $13.30 \pm 4.71 \mathrm{ab}$ & $6.70 \pm 4.71 \mathrm{ab}$ \\
\hline 0.5 & 1 & 0.5 & $96.70 \pm 4.71 \mathrm{c}$ & $30.0 \pm 0 \mathrm{~cd}$ \\
\hline 1 & 1 & 0.5 & $16.70 \pm 4.71 \mathrm{~b}$ & $40.0 \pm 8.16 \mathrm{~d}$ \\
\hline 0.5 & 0.5 & 1 & $0 \mathrm{a}$ & 0 \\
\hline 1 & 0.5 & 1 & $0 \mathrm{a}$ & 0 \\
\hline 0.5 & 1 & 1 & $46.66 \pm 9.42 \mathrm{~d}$ & $13.33 \pm 4.71 b$ \\
\hline 1 & 1 & 1 & $13.33 \pm 4.17 \mathrm{ab}$ & $26.70 \pm 4.71 \mathrm{c}$ \\
\hline
\end{tabular}

Each value represents the mean \pm SE of three independent experiments. Values in the same column with different letters are significantly different by Tukey's test $(P<0.05)$. Shoot induction was evaluated on day 21. $\mathrm{NXB}=$ internode with axillary buds; $\mathrm{BA}=\mathrm{N} 6$-benzyladenine; IAA $=$ indole-3-acetic acid; NAA $=$ $\alpha$-naphthalene-acetic acid. 


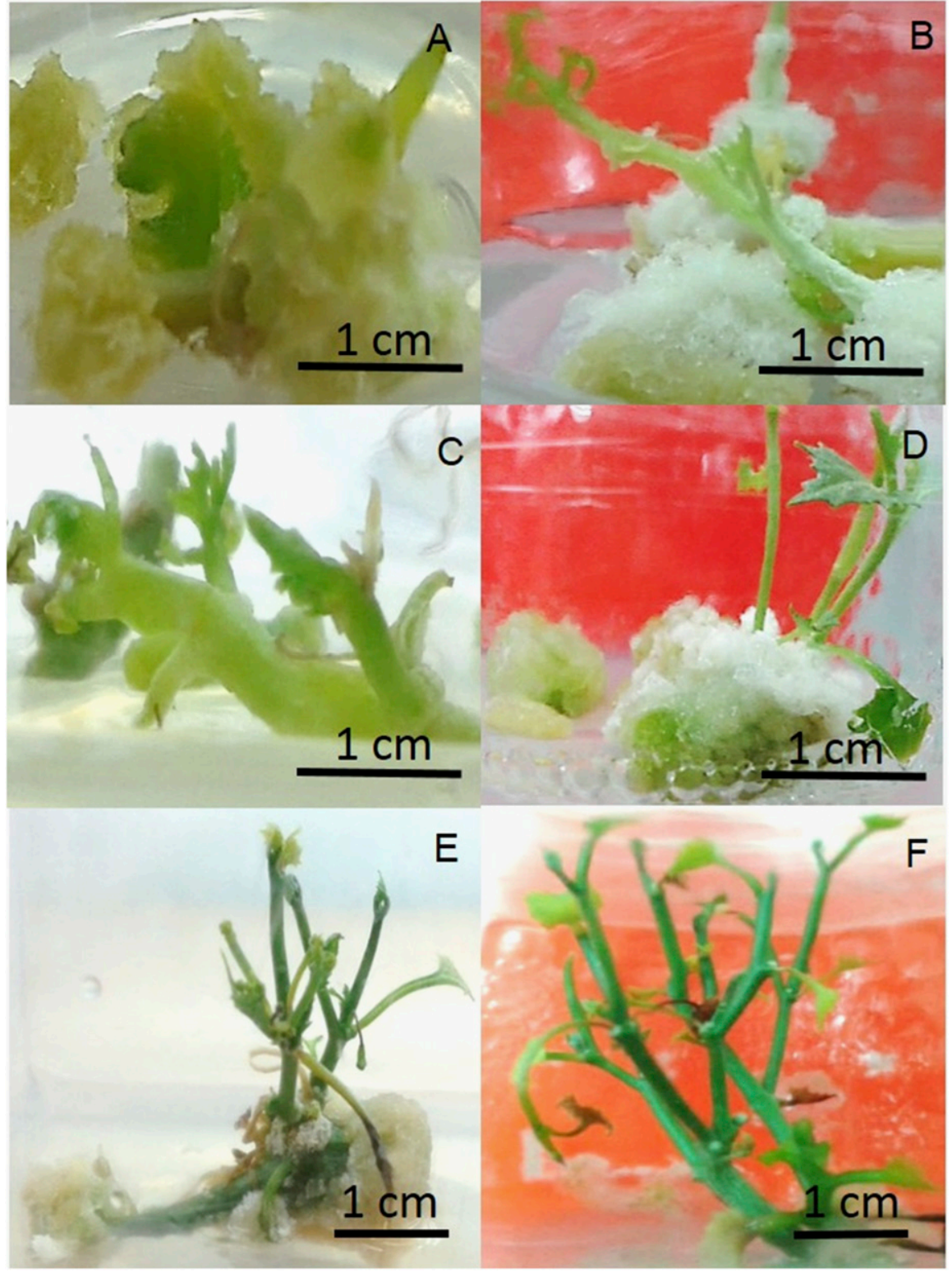

Fig. 1. Regeneration of shoots in I. sonorae NXB explants grown in optimized MR medium. (A) green friable organogenic callus on day 5, (B) white friable organogenic callus on day 7 with regenerated shoots, $(\mathbf{C})$ regenerated shoots after $15 \mathrm{~d}$ in green callus, (D) regenerated and proliferating shoots on day 15, (E) elongation of shoots, and (F) regenerating shoots selected for rooting $(20 \mathrm{~d})$.

Table 2. Frequency and weight of organogenic calli in NXB explants from I. sonorae.

\begin{tabular}{lccc}
\hline Calli & Calli induction (\%) & Explant wt (g) & Calli wt (g) \\
\hline White & $72.7 \pm 2.0 \mathrm{a}$ & $1.0 \pm 0.05$ & $4.59 \pm 0.12$ \\
Green & $27.2 \pm 0.5 \mathrm{~b}$ & $0.9 \pm 0.28$ & $4.02 \pm 0.79$ \\
\hline
\end{tabular}

Each value represents the mean $\pm \mathrm{SE}$ of three replicates. Values that do not share a letter are significantly different according to Student's test $(P \leq 0.05)$. The percent of induced calli and the mass of calli were assessed on day 15 . The mass of the explant was measured on the first day.

Table 3. Frequency of regenerating shoots from calli in NXB I. sonorae explants.

\begin{tabular}{lcc}
\hline Calli & Regenerating shoots (\%) & Number of shoots per explant \\
\hline White & $87.5 \pm 14.4 \mathrm{a}$ & $9.17 \pm 2.95$ \\
Green & $25.0 \pm 4.04 \mathrm{~b}$ & $2.33 \pm 0.57$
\end{tabular}

Each value represents the mean \pm SE of three replicates. Values that do not share a letter in the same column are significantly different according to Student's test $(P \leq 0.05)$. Percent of regenerating shoots was assessed on day 21 . roots and did not survive beyond day 15 . Survivors at $0.5 \mathrm{mg} \cdot \mathrm{L}^{-1}$ IBA exhibited thin primary roots without lateral roots $(0.5 \pm 0.47$ roots) on day 21 (Table 4). Meanwhile, root induction gradually increased to $20 \%$ in the medium supplemented with $1.0 \mathrm{mg} \cdot \mathrm{L}^{-1} \mathrm{IBA}$ attaining $1.25 \pm 0.94$ roots per regenerated shoot. At $2.0 \mathrm{mg} \cdot \mathrm{L}^{-1} \mathrm{IBA}$ and $21 \mathrm{~d}$ of culture, the plantlets displayed fasciculate thin roots (Fig. 2A) and primary thick taproot with lateral roots (Fig. 2B) and yielded the highest rooting frequency of $83.3 \%$ (Table 4 ). The result of the specimen selected for acclimatization on day 25 (Fig. 2C) shows a robust increase in root induction accompanied by larger number of roots $(4.25 \pm 0.98)$. At $3 \mathrm{mg} \cdot \mathrm{mL}^{-1}$ IBA, emergence of thin primary fasciculate roots declined by $40 \%$ compared with $2 \mathrm{mg} \cdot \mathrm{L}^{-1}$ IBA (Fig. 2D; Table 4). On day 25 , regenerated plantlets with primary and secondary roots were transferred to small plastic pots with sterilized soil (Fig. 2E), and $50 \pm 0.5 \%$ (Table 4 ) of these plantlets survived after culturing for $30 \mathrm{~d}$ (Fig. $2 \mathrm{E}$ and F).

\section{Discussion}

Callus induction and shoot regeneration. Micropropagation is a tissue culture technique to propagate species with slow growth in their natural habitat, production of plant free of pathogens, year around nursery of plantlets, clonal propagation of parental stocks, production of germplasm and implicit with this, preservation of endangered species. The aim of this study was to establish a protocol for micropropagation using NXB explants from $I$. sonorae. Initially, we investigated the most efficient culture media and auxin/cytokinin ratio for callus and shoot induction in $I$. sonorae $\mathrm{NBX}$ explants. We found that $\mathrm{B} 5$ medium was 3.2-fold more efficacious to induce callus than MS medium under equivalent conditions (unpublished data). Similarly, B5 medium induced 2.2-fold more shoots than MS medium (Table 1). Possibly, this organogenic efficacy of B5 medium is due to its higher content in vitamins (Smith, 2013).

We now demonstrate that optimized MR medium comprising $1.5 \mathrm{mg} \cdot \mathrm{L}^{-1}$ auxin (IAA + $\mathrm{NAA}$ ) and $0.5 \mathrm{mg} \cdot \mathrm{L}^{-1}$ cytokinin (BA) with molar ratio 3.8:1 induced high percentage of organogenic friable calli in I. sonorae NXB explants on day 15 (Fig. 1B) and promoted shoot induction as well (Fig. 1C and D). Inclusion of IAA was based on the notion that it participates during the developmental and growing stages, coordinating plant metabolism (synthesis, conjugation, hydrolysis, oxidation, and transport) in cucurbitaceous, more efficiently than NAA or 2,4-D (Lee et al., 2010; Normanly et al., 1995). The auxins IAA and NAA have been reported to promote callus formation and new shoots in tissue culture of cucurbitaceous Cucumis metuliferus (Compton and Gray, 1993). Prior reports showed that high auxin/cytokinin ratio enhances root formation in explants of Melothria maderaspatana and during generation of organogenic callus in Cucumis 
Table 4. Effect of IBA concentration on root induction of regenerated shoots from I. sonorae.

\begin{tabular}{lcccc}
\hline IBA $\left(\mathrm{mg} \cdot \mathrm{L}^{-1}\right)$ & Root induction (\%) & Roots per regenerated shoot & Root length & Survival in soil (\%) \\
\hline 0 & 0 & 0 & 0 & 0 \\
0.5 & $6.60 \pm 5.7 \mathrm{c}$ & $0.50 \pm 0.47$ & $0.75 \pm 0.70$ & 0 \\
1 & $20.0 \pm 10 \mathrm{c}$ & $1.25 \pm 0.94$ & $2.25 \pm 1$ & $5.01 \pm 0.81$ \\
2 & $83.30 \pm 2.3 \mathrm{a}$ & $4.25 \pm 0.98$ & $6.25 \pm 0.95$ & $50 \pm 0.5 \%$ \\
3 & $43.30 \pm 5.7 \mathrm{~b}$ & $3.03 \pm 0.81$ & 0 \\
\hline
\end{tabular}

Each value represents the mean \pm SE of three replicates. Values that do not share a letter are significantly different according to Tukey's test $(P<0.05)$. Percent root induction, the number of roots per shoot and root length were evaluated on day 21. Plant survival was recorded on day 30 . IBA $=$ indole-3-butyric acid.

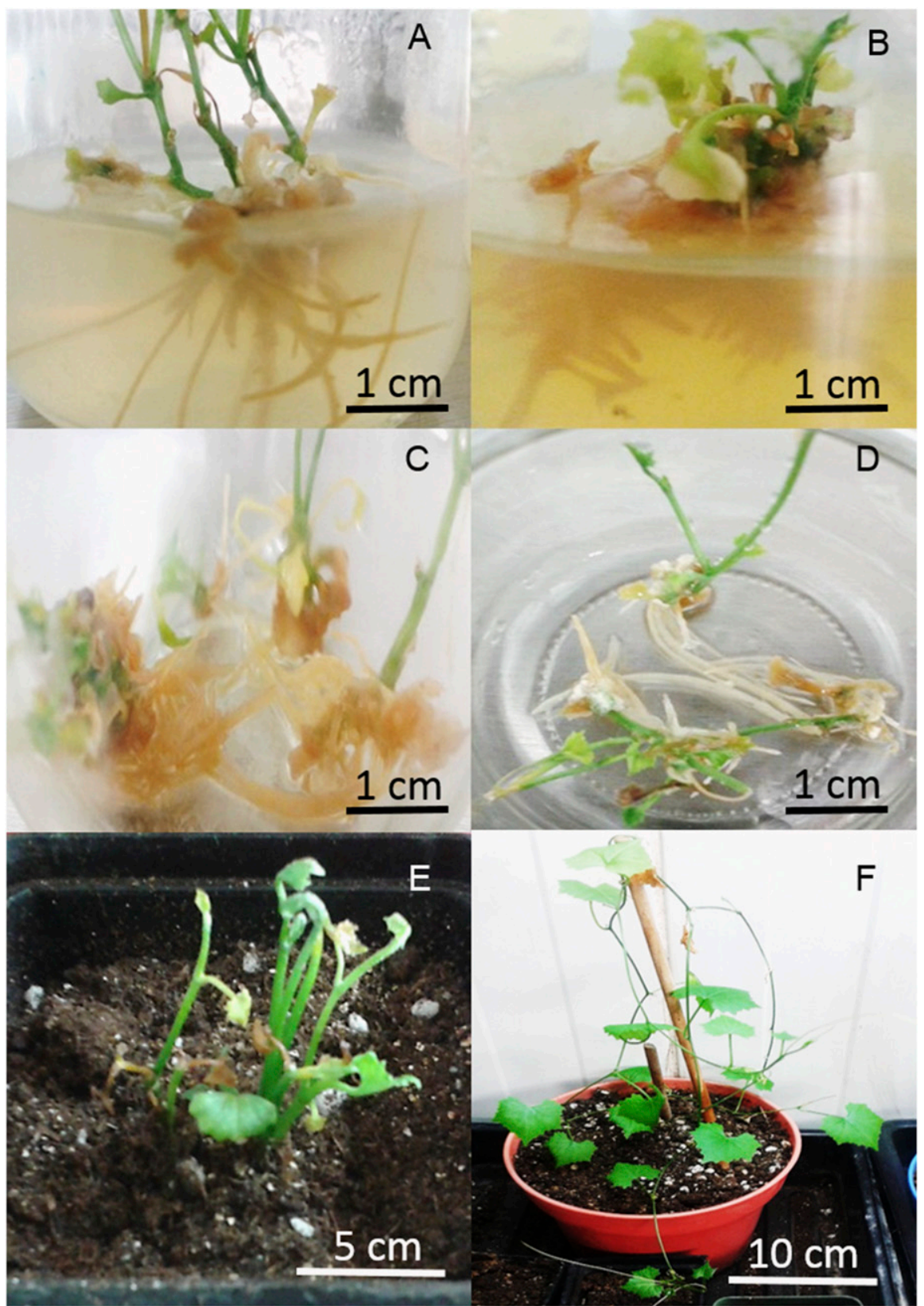

Fig. 2. Root induction from I. sonorae regenerated shoots. (A) Plantlet with primary thick root induced on B5 medium with $2 \mathrm{mg} \cdot \mathrm{L}^{-1}$ IBA for $21 \mathrm{~d}$, (B) Plantlet with primary thin roots induced on B5 medium plus $2 \mathrm{mg} \cdot \mathrm{L}^{-1} \mathrm{IBA}$, and (C) Roots from plantlets 5-6 cm length, (D) Plantlet with primary thin roots induced in $\mathrm{B} 5$ medium plus $3 \mathrm{mg} \cdot \mathrm{L}^{-1} \mathrm{IBA},(\mathbf{E})$ ex vitro in soil acclimatization of regenerated plantlet with roots on day 5 pretreated with $2 \mathrm{mg} \cdot \mathrm{L}^{-1} \mathrm{IBA}$, and $(\mathbf{F})$ ex vitro in soil acclimatization of regenerated plantlets with roots on day 30 pretreated with $2 \mathrm{mg} \cdot \mathrm{L}^{-1} \mathrm{IBA}$

sativus (Baskaran et al., 2009; Kakani et al., 2009; Selvaraj et al., 2007), while low auxin/ cytokinin ratio privileges shoot formation, although in this study we observe an increase of shoot production with high auxin/cytokinin values.

In previous studies, the stimulatory effect of BA combined with IAA in Cucumis melo was shown to be more efficient for calli formation than BA plus NAA or 2,4-D (Tabei et al., 1991). However, Valdez-Melara and Gatica-Arias (2009) demonstrated that the superior effect elicited by BA-IAA in C. melo depended on the genotype used. Also, the authors noted that regardless the genotype, supplementation of medium with BA alone without auxins was able to sustain shoot emergence. These results depart from what is observed in I. sonorae where IAA, NAA, and BA are essential for shoot emergence. Differences in the requirement of growth regulators highlight the relevance of variations between species that must be taken into account during micropropagation studies.

Results of induction of organogenic calli or shoot induction, similar to those reported here were described on cultures using axillary buds of nodal explants in cucurbitaceous Momordica charantia L. $\left(0.5 \mathrm{mg} \cdot \mathrm{L}^{-1} \mathrm{BA}\right.$ and $2.0 \mathrm{mg} \cdot \mathrm{L}^{-1} \mathrm{NAA}$ ) (Agarwal and Kamal, 2007), in hypocotyl and leaf explants of Cucumis anguria L. $\left(0.5 \mathrm{mg} \cdot \mathrm{L}^{-1} \mathrm{BA}\right.$ and $1.5 \mathrm{mg} \cdot \mathrm{L}^{-1}$ of $2,4-\mathrm{D}, 1.5 \mathrm{mg} \cdot \mathrm{L}^{-1}$ IAA) (Ju et al., 2014) during propagation in Momordica balsamina using $1.0 \mathrm{mg} \cdot \mathrm{L}^{-1} \mathrm{BA}$ (Thakur et al., 2011) and callus induction and plantlet regeneration of Citrullus colocynthis (Cucurbitaceae) with $0.5 \mathrm{mg} \cdot \mathrm{L}^{-1}$ IAA, $0.5 \mathrm{mg} \cdot \mathrm{L}^{-1}$ 2,4-D, and $1 \mathrm{mg} \cdot \mathrm{L}^{-1} \mathrm{BA}$ (Satyavani et al., 2011).

The role of cytokinins and auxins as agents for organogenesis has been discussed earlier. Agarwal (2015) proposed that cytokinins activate totipotent cells in callus for shoot organogenesis whereas in the case of direct organogenesis, these molecules activate preexisting machinery pertaining to somatic cells. Cytokinins in shoots stimulate growth because of the presence of meristematic cells located at the tip of explants, whereas auxins regulate or influence diverse responses at the whole-plant level, by mechanisms such as tropisms, apical dominance and root initiation, and by triggering cellular responses such as cell enlargement, division, and reactivation of differentiated cells to promote additional vascular tissue development and regulating lateral organ formation (Hagen and Guilfoyle, 2002; Mockaitis and Estelle, 2008).

Although the mean number of shoots per explant obtained in I. sonorae was lower when compared with Citrullus colocynthis (Meena et al., 2013) or Momordica charantia (Thiruvengadam et al., 2012), their inception within two weeks is somewhat earlier than in most regenerating systems. Interestingly, most examples describing regeneration of 
organogenic callus include two regulators ( 1 auxin and 1 cytokinin), while in this work we maximize calli production by using 2 auxins and 1 cytokinin.

The rationale for using axillary buds as vehicle for micropropagation rests on the notion that they are able to preserve the genetic traits due to the presence of meristematic tissue (Souza et al., 2006). This notion is supported by studies, showing that many of the propagated plants in Echinocereus cinerascens and Momordica dioica when derived from axillary buds displayed higher genetic stability and uniformity (Elias et al., 2015; Thiruvengadam et al., 2006). Our results showed that the optimized MR medium enhanced the growth of regenerated shoots, and preserved them in fair condition without damage or loss during the $15 \mathrm{~d}$ experimental period, obviating the need for further passage to an elongation medium.

Root induction. The efficacy of root induction seen in I. sonorae regenerating shoots at $2.0 \mathrm{mg} \cdot \mathrm{L}^{-1}$ IBA was also demonstrated in Stackhousia tryonii, M. dioica, Citrullus lanatus, Momordica cymbalaria, and Cucumis sativus (Bhatia et al., 2002; Selvaraj et al., 2007; Thiruvengadam et al., 2006). In S. tryonii, Bhatia et al. (2002) also reported that IBA was more effective than IAA and NAA for rooting, thus justifying its application as root inducer in many cucurbitaceous. In M. balsamina, a dose dependent effect on rooting has been demonstrated with maximal activity at $1.5 \mathrm{mg} \cdot \mathrm{L}^{-1}$ of IBA (Thakur et al., 2011).

IBA has been used in commercial agriculture as well for its capacity in plants to promote cuttings, root initiation/growth, inhibition of primary root elongation, and stimulation of lateral root formation (Zažímalová et al., 2014). In I. sonorae, regenerating shoots in B5 medium supplemented with $2.0 \mathrm{mg} \cdot \mathrm{L}^{-1}$ IBA there was a strong induction of roots attaining $83.3 \%$ (Table 4). In contrast, Yan et al. (2010) observed no significant difference on rooting rate in vitro and ex vitro in Siratia grosvenorii. However, in vitro developed roots in $S$. grosvenorii were thick, fragile, and easily broken while handling. Because of this difference, ex vitro rooting was preferable as it promoted higher percent survival rate. In I. sonorae, we detected $50 \%$ survival for plantlets regenerated following treatment with $2.0 \mathrm{mg} \cdot \mathrm{L}^{-1} \mathrm{IBA}$ and acclimatized in small pots for $30 \mathrm{~d}$.

Interestingly, tuberous root of I. sonorae has been demonstrated to possess pharmacological activity. To date, no report exists on micropropagation or induction of tuberous root of $I$. sonorae in vitro or even the procedure to modulate its growth in soil. Rooting similar to that observed in this study is found in field specimens of I. sonorae; hence, investigating the presence of biologically active metabolites in in vitro grown roots is essential to confirm the presence of hypoglycemic activity. Fan et al. (2011) reported that in Manihot esculenta combinations, auxins and cytokinins are necessary to induce tuberous roots in vitro, and the absence of one of them in the medium led to their decrease or full absence. According to our results, IBA alone induced thick taproots and moderated the number of fasciculate roots; thus, obviating the need for cytokinins during root development. Future studies aim to investigate if the regenerated roots arising in culture and roots developed in ex vitro plantlets contain the metabolites responsible for the medicinal properties in I sonorae.

\section{Conclusions}

This is the first report describing the in vitro micropropagation of I. sonorae through a simple and efficient protocol to induce shoots and rooting. Internode explants from this plant seem to be appropriate for the induction of organogenic calli and regenerated shoots under these experimental conditions. NXB explants grown on MR medium (B5 with $0.5 \mathrm{mg} \cdot \mathrm{L}^{-1} \mathrm{NAA}, 0.5 \mathrm{mg} \cdot \mathrm{L}^{-1} \mathrm{BA}$, and $1.0 \mathrm{mg} \cdot \mathrm{L}^{-1} \mathrm{IAA}$ ) promoted shoot proliferation and their elongation during a 3-week period. Furthermore, only one medium was required to induce and elongate shoots by day 15 obviating the need of a further passage. In B5 medium supplemented with IBA, a strong rooting response was observed displaying long thick roots with potential to become tuberous roots. This protocol is of interest for industrial propagation of the species for eventual production of secondary metabolites and for preservation of I. sonorae.

\section{Literature Cited}

Achenbach, H., K. Horn, X.A. Dominguez, and E.G. Gómez-López. 1993. Cucurbitanes and cucurbitane-type Ibervillea sonorae. Phytochemistry 33:437-445.

Agarwal, M. 2015. Tissue culture of Momordica charantia L. J. Plant Sci. 3:24-32.

Agarwal, M. and R. Kamal. 2007. Studies on flavonoid production using in vitro cultures of Momordica charantia L. Indian J. Biotechnol. 6:277-279.

Ahmad, N. and M. Anis. 2005. In vitro mass propagation of Cucumis sativus $\mathrm{L}$. from nodal segments. Turk. J. Bot. 29:237-240.

Aileni, M., S.R. Kota, V.R. Kokkirala, P. Umate, and S. Abbagani. 2009. Efficient in vitro regeneration and micropropagation of medicinal plant Momordica tuberosa Roxb. J. Herbs Spices Med. Plants 15:141-148.

Alarcon-Aguilar, F.J., F. Calzada-Bermejo, E. Hernandez-Galicia, C. Ruiz-Angeles, and R. Roman-Ramos. 2005. Acute and chronic hypoglycemic effect of Ibervillea sonorae root extracts-II. J. Ethnopharmacol. 97:447-452.

Arias, M., A. Aguirre, M. Angarita, C. Montoya, and J. Restrepo. 2009. Aspectos ingenieriles del cultivo in vitro de células vegetales para la producción de metabolitos secundarios. Dyna 76:109-121.

Baskaran, P., P. Velayutham, and N. Jayabalan. 2009. In vitro regeneration of Melothria maderaspatana via indirect organogenesis. In Vitro Cell. Dev. Biol. Plant 45:407-413.

Bhatia, N.P., P. Bhatia, and N. Ashwath. 2002. Ex vitro rooting of micropropagated shoots of Stackhousia tryonii. Biol. Plant. 45:441-444.

Compton, M.E. and D.J. Gray. 1993. Shoot organogenesis and plant regeneration from cotyledons of diploid, triploid and tetraploid watermelon. J. Amer. Soc. Hort. Sci. 118:151-157.
Devendra, N.K., Y.N. Seetharam, and B. Subhash. 2009. Callus growth and plant regeneration in Momordica dioica (Roxb.) Willd. Cucurbitaceae. Amer.-Eurasian J. Sustain. Agr. 3:743-748.

Elias, H., R.M. Taha, N.A. Hasbullah, N. Mohamed, A.A. Manan, N. Mahmad, and S. Mohajer. 2015. The effects of plant growth regulators on shoot formation, regeneration and coloured callus production in Echinocereus cinerascens in vitro. Plant Cell Tissue Organ. Cult. 120:729-739.

Estrada-Zuñiga, M.E., H. Arano-Varela, L. Buendía-González, and J. Orozco-Villafuerte. 2012. Fatty acids, phenols content, and antioxidant activity in Ibervillea sonorae callus cultures. Rev. Mex. Ing. Quim. 11:23-43.

Fan, M., Z. Liu, L. Zhou, T. Lin, Y. Liu, and L. Luo. 2011. Effects of plant growth regulators and saccharide on in vitro plant and tuberous root regeneration of cassava (Manihot esculenta Crantz). J. Plant Growth Regul. 30:11-19.

Gamborg, O.L., R.A. Miller, and K. Ojima. 1968. Nutrient requirements of suspension cultures of soybean root cell. Exp. Cell Res. 50:151-158.

Gardiner, W.P. and G. Gettinby. 1998. Experimental design techniques in statistical practice: A practical software-based approach. 1st ed. Horwood Publishing Ltd., England. p. 119-165.

Gómez-Aiza, A. 2011. Quemada: Reproducción humana y enfermedades culturales en la sierra Otomí-Tepehua, Hidalgo. Estud. Antropol. Biológica 15:273-313.

Hagen, G. and T. Guilfoyle. 2002. Auxinresponsive gene expression: Genes, promoters and regulatory factors. Plant Mol. Biol. 49: 373-385.

Jardón-Delgado, A., G.A. Magos-Guerrero, and M. Martínez-Vázquez. 2014. Isolation of a new anti-inflammatory $20,21,22,23,24,25,26,27$ octanorcucurbitacin-type triterpene from Ibervillea sonorae. Nat. Prod. Commun. 9:15-16.

Johnson, G.D., S.S.F. Moreno, and E.R. López. 1996. Compendio fitoquímico de la medicina tradicional herbolaria de Sonora. Universidad de Sonora, Sonora, Hermosillo, México. p. 127-128.

Ju, H.J., J. Jeyakumar, M. Kamaraj, N. Praveen, I.M. Chung, S.H. Kim, and M. Thiruvengadam. 2014. High frequency somatic embryogenesis and plant regeneration from hypocotyl and leaf explants of gherkin (Cucumis anguria L.). Sci. Hort. 169:161-168.

Kakani, A., L. Guosheng, and Z. Peng. 2009. Role of aux 1 in the control of organ identity during in vitro organogenesis and in mediating tissue specific auxin and cytokinin interaction in Arabidopsis. Planta 229:625-657.

Kathiravan, K., G. Vengedesan, S. Singer, B. Steinitz, H.S. Paris, and V. Gaba. 2006. Adventitious regeneration in vitro occurs across a wide spectrum of squash (Cucurbita pepo) genotypes. Plant Cell Tissue Organ. Cult. 85:285-295.

Kim, K.M., K.K. Chang, and S.H. Jeung. 2010. In vitro regeneration from cotyledon explants in figleaf gourd (Cucurbita ficifolia Bouché), a rootstock for Cucurbitaceae. Plant Biotechnol. Rep. 4:101-107.

Kumar, A.H.G., H.N. Murthy, and K.Y. Paek. 2003a. Embryogenesis and plant regeneration from anther cultures of Cucumis sativus L. Sci. Hort. 98:213-222.

Kumar, S., M. Singh, A.K. Singh, K. Srivastava, and M.K. Banerjee. 2003b. In vitro propagation of pointed gourd (Trichosanthes dioica Roxb.). Cucurbit Genet. Coop. Rep. 26:74-75.

Lee, Y., D.E. Lee, H.S. Lee, S.K. Kim, W.S. Lee, S.H. Kim, and M.W. Kim. 2010. Influence of auxins, cytokinins, and nitrogen on production 
of rutin from callus and adventitious roots of the white mulberry tree (Morus alba L.). Plant Cell. Tissue Organ. Cult. 105:9-19.

Lee, Y.K., W.I. Chung, and H. Ezura. 2003. Efficient plant regeneration via organogenesis in winter squash (Cucurbita maxima Duch). Plant Sci. 164:413-418.

Lira, R. and J. Caballero. 2002. Ethnobotany of the wild Mexican Cucurbitaceae. Econ. Bot. 56:380-398.

Loraine, S. and J.A. Mendoza-Espinoza. 2010. Medicinal plants as potential agents against cancer, relevance for Mexico. Rev. Mex. Cienc. Farm. 41:18-27.

Meena, M., R. Meena, and V. Patni. 2013. High frequency plant regeneration from shoot tip explants of Citrullus colocynthis (Linn.) Schrad.-An important medicinal herb. Afr. J. Biotechnol. 9:5037-5041.

Mockaitis, K. and M. Estelle. 2008. Auxin receptors and plant development: A new signaling paradigm. Annu. Rev. Cell Dev. Biol. 24:55-80.

Murashige, T. and F. Skoog. 1962. A revised medium for rapid growth and bioassays with tobacco tissue cultures. Physiol. Plant. $15: 473-497$

Normanly, J., J.P. Slovin, and J.D. Cohen. 1995. Rethinking auxin biosynthesis and metabolism. Plant Physiol. 107:323-329.

Rao, S.R. and G.A. Ravishankar. 2002. Plant cell cultures: Chemical factories of secondary metabolites. Biotechnol. Adv. 20:101-153.

Rivera-Ramírez, F., G.N. Escalona-Cardoso, L. Garduño-Siciliano, C. Galaviz-Hernández, and N. Paniagua-Castro. 2011. Antiobesity and hypoglycaemic effects of aqueous extract of Ibervillea sonorae in mice fed a high-fat diet with fructose. J. Biomed. Biotechnol. 2011:1-6.

Robles-Zepeda, R.E., C.A. Velázquez-Contreras, A. Garibay-Escobar, J.C. Gálvez-Ruiz, and E. Ruiz-Bustos. 2011. Antimicrobial activity of northwestern Mexican plants against Helicobacter pylori. J. Med. Food 14: 1280-1283.
Roy, C.K., J.L. Munshia, N. Begum, R. Kathun, and A.K.M.S. Hassanb. 2012. In vitro plant regeneration of Coccinea cordifolia (Linn.) Cogn., an anti-diabetic medicinal plant. Bangladesh J. Sci. Ind. Res. 47:187-190.

Ruiz-Bustos, E., C. Velázquez, A. Garibay-Escobar, Z. García, M. Plascencia-Jatomea, M.O. CortezRocha, J. Hernandez-Martínez, and R.E. RoblesZepeda. 2009. Antibacterial and antifungal activities of some Mexican medicinal plants. J. Med. Food 12:1398-1402.

Sammaiah, D., T. Srilatha, D.U. Anitha, and T. Ugandhar. 2014. Plantlet regeneration from leaf explants through organogenesis in bitter melon (Momordica charantia L.). Acad. J. Interdiscipl. Stud. 3:79-84.

Satyavani, K., T. Ramanathan, and S. Gurudeeban. 2011. Effect of plant growth regulators on callus induction and plantlet regeneration of bitter apple (Citrullus colocynthis) from stem explant. Asian J. Biotechnol. 3:246-253.

Selvaraj, N., A. Vasudevan, M. Manickavasagam, S. Kasthurirengan, and A. Ganapathi. 2007. High frequency shoot regeneration from cotyledon explants of cucumber via organogenesis. Sci. Hort. 112:2-8.

Smith, R. 2013. Plant tissue culture: Techniques and experiments media components and preparation, p. 31-40. Media components and preparation. 3rd ed, Chapter 3. Elsevier-AP.

Souza, F.V.D., B. Garcia-Sogo, and A.S. Souza. 2006. Morphogenetic response of cotyledon and leaf explants of melon (Cucumis melo L.) cv. amarillo oro. Braz. Arch. Biol. Technol. 49:21-27.

Tabei, Y., T. Kanno, and T. Nishio. 1991. Regulation of organogenesis and somatic embryogenesis by auxin in melon, Cucumis melo L. Plant Cell Rpt. 10:225-229.

Thakur, G.S., M. Pandey, R. Sharma, B.S. Sanodiya, G.B.K.S. Prasad, and P.S. Bisen. 2011. Factors affecting in vitro propagation of Momordica balsamina: A medicinal and nutritional climber. Physiol. Mol. Biol. Plants 17: 193-197.
Thiruvengadam, M., K.T. Rekha, and N. Jayabalan. 2006. An efficient in vitro propagation of Momordica dioica Roxb. Ex Willd. Philippine Agr. Sci. 89:165-171.

Thiruvengadam, M., N. Praveen, and I.M. Chung. 2012. In vitro regeneration from internodal explants of bitter melon (Momordica charantia L.) via indirect organogenesis. Afr. J. Biotechnol. 11:8218-8224.

Thomas, T.D. and K.R. Sreejesh. 2004. Callus induction and plant regeneration from cotyledonary explants of ash gourd (Benincasa hispida L.). Sci. Hort. 100:359-367.

Valdez-Melara, M. and A. Gatica-Arias. 2009. Effect of BAP and IAA on shoot regeneration in cotyledonary explants of Costa Rican melon genotypes. Agron. Costarric. 33:125-131.

Xolalpa, S. 2002. La herbolaria Mexicana en el tratamiento de la diabetes. Ciencia 53:2435.

Xolalpa, S. and A. Aguilar. 2006. XXXIII Uma ética para quantos? Riquezas del bosque: Frutas, remedios y artesanías en América Latina. El País, p. 102-105. In: C. López, P. Shanley, and M.C. Cronkleton (eds.). 1st ed. Santa Cruz, Bolivia.

Yan, H., C. Liang, L. Yang, and Y. Li. 2010. In vitro and ex vitro rooting of Siratia grosvenorii, a traditional medicinal plant. Acta Physiol. Plant. 32:115-120.

Zohura, F.T., M.E. Haque, M.A. Islam, M. Khalekuzzaman, and B. Sikdar. 2013. Establishment of an efficient in vitro regeneration system of ridge gourd (Luffa acutangula L. Roxb) from immature embryo and cotyledon explants. Intl. J. Sci. Technol. Res. 2:33-37.

Zapata-Bustos, R., A.J. Alonso-Castro, M. GómezSánchez, and L.A. Salazar-Olivo. 2014. Ibervillea sonorae (Cucurbitaceae) induces the glucose uptake in human adipocytes by activating a PI3K-independent pathway. J. Ethnopharmacol. 152:546-552.

Zažímalová, E., J. Petrasek, and E. Benková. 2014. Auxin and its role in plant development. Springer-Verlag, Vienna, Austria. 33:21-33. 